\title{
Effect of Flooding Under the Gas Exchange of Cocoa Seedlings
}

\author{
Vinicius de Souza Oliveira ${ }^{1}$, Ana Paula Braido Pinheiro ${ }^{1}$, Basílio Cerri Neto ${ }^{2}$, Sara Dousseau Arantes ${ }^{3}$, \\ Cleidson Alves da Silva ${ }^{1}$, Jeane Crasque ${ }^{1}$, Maria Luiza Pereira Barbosa Pinto ${ }^{1}$, Gleyce Pereira Santos ${ }^{1}$, \\ André Lucas Reboli Pagoto ${ }^{1}$, Adriel Lima Nascimento ${ }^{4}$, José Altino Machado Filho ${ }^{3}$, Robson Prucoli Posse ${ }^{5}$, \\ Sheila Cristina Prucoli Posse ${ }^{6}$, Carlos Alberto Spaggiari Souza ${ }^{7}$, Omar Schmildt ${ }^{1} \&$ Edilson Romais Schmildt $^{8}$ \\ ${ }^{1}$ Postgraduate Program in Tropical Agriculture, Federal University of Espírito Santo, São Mateus, ES, Brazil \\ ${ }^{2}$ Postgraduate Program in Plant Biology, Federal University of Espírito Santo, Vitória, ES, Brazil \\ ${ }^{3}$ Capixaba Institute for Research, Technical Assistance and Rural Extension, Regional Center for Rural \\ Development, Brazil \\ ${ }^{4}$ Federal University of Espírito Santo, Alegre, ES, Brazil \\ ${ }^{5}$ Federal Institute of Espírito Santo-Campus Itapina, Colatina, Espírito Santo, Brazil \\ ${ }^{6}$ Capixaba Institute for Research, Technical Assistance and Rural Extension, Vitória, ES, Brazil \\ ${ }^{7}$ Cacao Research Station "Filogônio Peixoto" (CEPLAC), Linhares, Espírito Santo, Brazil \\ ${ }^{8}$ Departament of Agrarian and Biological Sciences, Federal University of Espírito Santo, São Mateus, ES, Brazil \\ Correspondence: Vinicius de Souza Oliveira, Postgraduate Program in Tropical Agriculture, Federal University \\ of Espírito Santo, São Mateus, ES, Brazil. E-mail: souzaoliveiravini@gmail.com
}

Received: July 11, 2019

doi:10.5539/jas.v11n16p233
Accepted: August 16, $2019 \quad$ Online Published: September 30, 2019

URL: https://doi.org/10.5539/jas.v11n16p233

\begin{abstract}
Under flooding conditions, plants exhibit morphological and physiological characteristics that indicate that the plant is undergoing stress. In this sense, the objective of this work was to evaluate the gas exchange of cocoa (Theobroma cacao L.) seedlings submitted to different times of flooding. The study was carried out at the experimental farm of the Capixaba Institute for Research Technical Assistance and Rural Extension, in Linhares, North of the State of Espírito Santo, Brazil. The experimental design was completely randomized. The treatments consisted in the flooding of the seedlings on days 0 (without flooding), 1, 2, 4 and 8 . The seedlings were evaluated for gas exchange by characteristics: liquid assimilation of $\mathrm{CO}_{2}$; stomatal conductance; transpiration rate; water use efficiency. The gas exchange of cocoa seedlings were influenced by the flooding period in which they were submitted with a decrease in the values liquid assimilation of $\mathrm{CO}_{2}$, stomatal conductance and transpiration rate after the fourth day of flooding, after this period the seedlings developed morphological modifications that allowed them to adapt the flooding conditions, improving the liquid assimilation of $\mathrm{CO}_{2}$.
\end{abstract}

Keywords: Theobroma cacao L., water stress, oxygen deficiency

\section{Introduction}

Cocoa (Theobroma cacao L.) is a species with a center of origin in the Amazon, belongs to the Malvaceae family, being a dicot that can reach up to $20 \mathrm{~m}$ high in wild conditions, but under cultivation it is between 3 and $5 \mathrm{~m}$ of height. The seeds extracted from the fruits are of great economic importance, being raw material for the manufacture of chocolate (Brasil, 2014). Brazilian cocoa production is distributed in the North, Northeast, Southeast and Midwest regions and in 2017 totaled 214,348 tons. Among the main producing states are Pará, Bahia and Espírito Santo with $54.36 \%, 39.12 \%$ and 3.12\%, respectively, of the national production (IBGE, 2018).

The crop develops well in areas with annual rainfall between 1,500 and 2,000 $\mathrm{mm}$, but both water scarcity and excess (flooding) are detrimental to crops. In some cocoa producing regions subject to periodic flooding, this has been a limiting factor for the initial growth and establishment of the crop (Gomes \& Kozlowski, 1986). Most of the cocoa planted in the northern region of Espírito Santo is cultivated in alluvial soils that are suitable for flooding in the summer (Souza et al., 2005). 
Flooding can lead to plant deficiency or lack of oxygen in the root zone, causing slow diffusion of $\mathrm{O}_{2}$ in saturated soils. In the aerobic respiration pathway, oxygen is the final acceptor of electrons in oxidative phosphorylation and in several crucial biosynthetic pathways, such as the synthesis of chlorophyll, fatty acids and steroids; however, under anaerobiosis, glycolysis and fermentation may exceed metabolism aerobic and become the only route of energy production (Dennis et al., 2000; Souza \& Sodek, 2002).

Under flood, the plants present morphological and physiological characteristics that indicate that the plant is undergoing stress, among the morphological ones are hypertrophied lenticels, aerenchyma formation and adventitious roots, mechanisms that increase the availability of oxygen in the tissues. As regards the physiological characteristics, it can be observed a reduction of the photosynthetic rate due to the stomatal closure, alterations in the partition of photoassimilates (source-drain relation), reduction of nutrient absorption, changes in hormonal homeostasis, predominantly the increase of ethylene and abscisic acid synthesis (Bertolde et al., 2012).

Thus, the objective of this study was to evaluate the gas exchange of cocoa (Theobroma cacao L.) seedlings submitted to different flooding times.

\section{Method}

The study was carried out at the experimental farm of the Capixaba Research Institute for Technical Assistance and Rural Extension in Linhares, in the north of the State of Espírito Santo, Brazil, located at latitude $19^{\circ} 25^{\prime} 03^{\prime \prime}$ South and $40^{\circ} 04^{\prime} 50^{\prime \prime}$ west longitude. The region is characterized by tropical AW (tropical humid) climate, with rainfall in summer and dry winter according to köppen classification (Alvares et al., 2014).

The experiment was carried out in a greenhouse with black polypropylene screen with $50 \%$ shading. Inside the greenhouse were four flooded environments and an environment with no flooding. The seedlings used were 2 months old and were obtained from grafting of the CCN 51 genotype on the TSH 1188 genotype.

The experimental design was a completely randomized design. The treatments consisted in the flooding of the seedlings on days 0 (without flooding), 1, 2, 4 and 8 . The flooding was accomplished by placing cocoa seedlings in plastic buckets with capacity of $5 \mathrm{~L}$ filled with water. In the treatment without flooding, the seedlings were placed in perforated buckets to facilitate the flow of excess irrigation water. Three seedlings per treatment were used.

The seedlings were evaluated for gas exchange by characteristics: a) liquid assimilation of $\mathrm{CO}_{2}(\mathrm{~A})\left(\mu \mathrm{mol} \mathrm{CO}_{2}\right.$ $\left.\mathrm{m}^{-2} \mathrm{~s}^{-1}\right)$; b) stomatal conductance $\left(\mathrm{g}_{\mathrm{s}}\right)\left(\mathrm{mmol} \mathrm{H}_{2} \mathrm{O} \mathrm{m}^{-2} \mathrm{~s}^{-1}\right)$; $\left.\mathrm{c}\right)$ transpiration rate $(\mathrm{E})\left(\mathrm{mmol} \mathrm{m}^{-2} \mathrm{~s}^{-1}\right)$. The water use efficiency (WUE) $\left(\mu \mathrm{mol} \mathrm{mmol}{ }^{-1}\right)$ was obtained by the division between the liquid assimilation of $\mathrm{CO}_{2}$ and the transpiration rate $(\mathrm{A} / \mathrm{E})$. The measurements were performed with the IRGA open system (CIRAS 2, PP Systems, England) (Figure 1), with saturating irradiance of $3000 \mu \mathrm{mol} \mathrm{m}^{-2} \mathrm{~s}^{-1}$ of photons between 10:00 a.m. and 11:00 a.m. hours on the third fully expanded leaf of each seedlings.
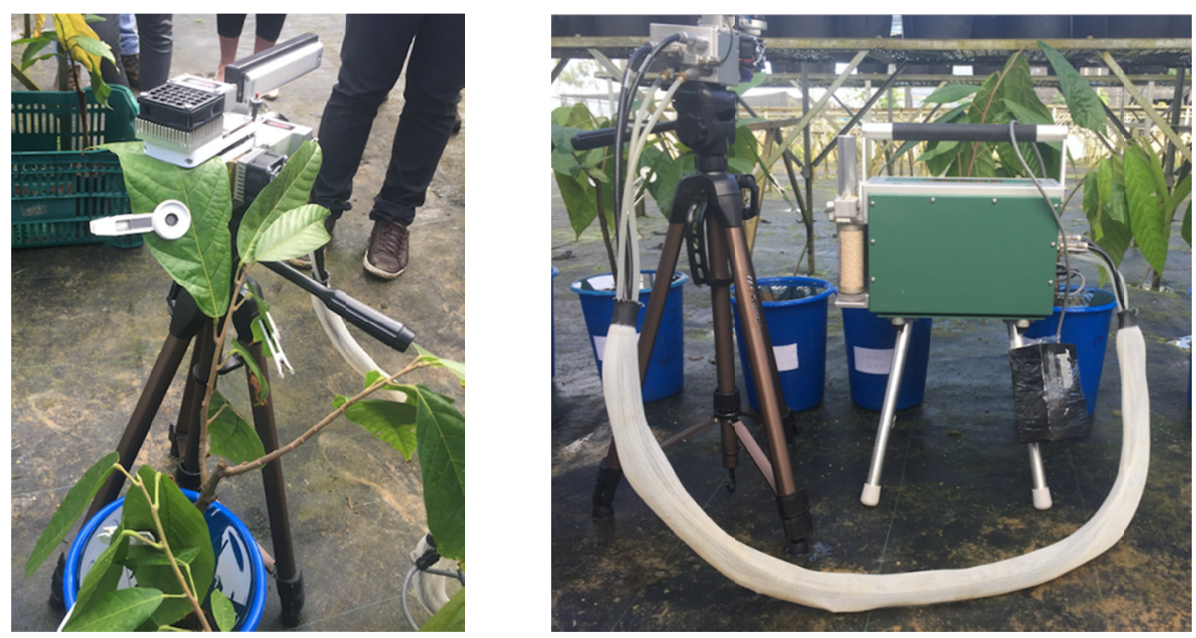

Figure 1. Measurements of gas exchange of cocoa seedlings (Theobroma cacao L.) with IRGA open system portable meter 
The results were submitted to analysis of variance and the effects of treatment were evaluated by the Tukey test at $5 \%$ probability with the aid of the statistical software $\mathrm{R}$ ( $\mathrm{R}$ Core Team, 2018).

\section{Results and Discussion}

In Table 1, it is possible to observe that, for the characteristics of analyzed gas exchanges, the plants showed a significant difference by the Tukey test $(\mathrm{p}<0.05)$, except for the water use efficiency (WUE). Under flooding conditions, the plants have their yield affected, as the excess water causes a decrease in the amount of oxygen and $\mathrm{CO}_{2}$, besides the decrease in aerobic respiration (Pires et al., 2002). These symptoms under unadapted plants, leads to reduction in development and consequently in their production.

Table 1. Liquid assimilation of $\mathrm{CO}_{2}(\mathrm{~A})$, stomatal conductance $\left(\mathrm{g}_{\mathrm{s}}\right)$, transpiration rate (E) and water use efficiency (WUE) of cocoa seedlings (Theobroma cacao L.) under different days of flooding

\begin{tabular}{lllll}
\hline Treatments & A & $\mathrm{g}_{\mathrm{s}}$ & $\mathrm{E}$ & WUE \\
\hline $0 \mathrm{DAF}$ & $10.270 \mathrm{a}$ & $0.210 \mathrm{a}$ & $3.640 \mathrm{a}$ & $2.840 \mathrm{a}$ \\
$2 \mathrm{DAF}$ & $5.390 \mathrm{ab}$ & $0.073 \mathrm{~b}$ & $1.550 \mathrm{~b}$ & $3.500 \mathrm{a}$ \\
$4 \mathrm{DAF}$ & $3.570 \mathrm{~b}$ & $0.056 \mathrm{~b}$ & $1.450 \mathrm{~b}$ & $3.030 \mathrm{a}$ \\
$8 \mathrm{DAF}$ & $5.210 \mathrm{ab}$ & $0.074 \mathrm{~b}$ & $1.120 \mathrm{~b}$ & $3.580 \mathrm{a}$ \\
\hline Mean & 6.110 & 0.103 & 1.940 & 3.240 \\
\hline CV $(\%)$ & 35.13 & 24.86 & 22.28 & 22.92 \\
\hline
\end{tabular}

Note. Means followed by the same letter in the column do not differ by Tukey's test $(\mathrm{p}<0.05)$.

$\mathrm{DAF}=$ Days after flooding.

The liquid assimilation of $\mathrm{CO}_{2}$ (A) of the cocoa seedlings was influenced by the time of flooding. The treatments with two and eight days after flooding presented statistically the same results as the non-flooded treatment, while the treatment with four days after flooding showed statistically lower results than the others. Under favorable conditions, plants tend to have greater liquid assimilation of $\mathrm{CO}_{2}$, which indicates greater light interception and better initial growth (Vivian et al., 2013).

At two days the plants were not affected by flooding, while on the fourth day the plants suffered a decrease in the liquid assimilation of $\mathrm{CO}_{2}$, indicating that the plants were under stress. The increase of the liquid assimilation of $\mathrm{CO}_{2}$ indicates that the plants after eight days of flooding presented morphophysiological changes, such as hypertrophic lenticels (Figure 2), showing that the plants developed flood tolerance mechanisms (Dennis et al., 2000). These structures provide increased oxygen availability in the internal tissues of plants (Bailey-Serres $\&$ Voeseneck, 2008). However, even the recovery process of normal levels of oxygen in the soil can be harmful to the plant, since much of this oxygen is transformed into compounds toxic to the plant, generating data to the root cells (Taiz el al., 2017).

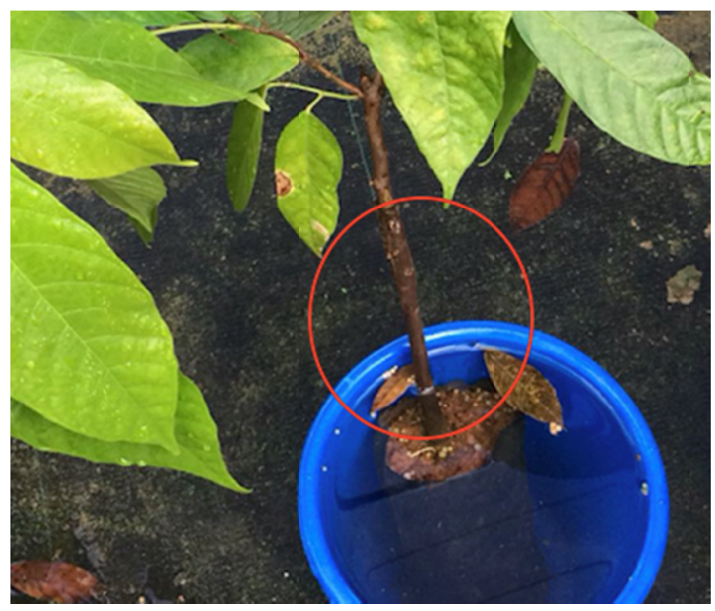

Figure 2. Hypertrophic lenticels observed in cocoa seedlings (Theobroma cacao L.) exposed to eight days of flooding 
In the present study, the plants in the treatment without flooding showed higher values of stomatal conductance $\left(\mathrm{g}_{\mathrm{s}}\right)$. However, the gs values did not differ statistically as the days went by in flooding (Table 1). These data corroborate with those found by Bertolde (2007), who when evaluating the TSH 1188 clone under flooding also observed a greater stomatal opening in a non-flooded environment.

Stomatal conductance is influenced by excess water. Flooding leads to stomatal closure by reducing the supply of $\mathrm{CO}_{2}$ to chloroplasts, promoting the overproduction of reactive oxygen species, causing damage to plant cells (Kalaji et al., 2017). In response to soil flooding, tolerant and non-tolerant plants reduce stomatal conductance. In a few weeks after this stress tolerant species tend to recover stomatal conductance values, coming close to the control (Kozlowiski, 1997; Mielke et al., 2005).

The reduction of the stomatal conductance may lead to a reduction of the photosynthesis process by the plants. However, the stress generated by the flooding is independent of the stomatal conductance values, since the flood may influence the photosynthetic apparatus directly (Oliveira \& Gualtieri, 2017). This is due to the limited regeneration capacity of the ribulose enzyme 1,5-biphosphate carboxylase (Rubisco) under such conditions, reducing the photosynthetic rate of plants (Parolin \& Wittmann, 2010; Pareek et al., 2010)

The transpiration rate (E) was affected by soil flooding, and the treatment without flooding was statistically superior to the others. This decrease in transpiration rate is expected in species considered sensitive when exposed to water stress (Kozlowisk, 1997; Wittmann, 2010). This occurs initially due to the stomatal closure, caused by the decrease of oxygen in the soil resulting in the decline of $\mathrm{CO}_{2}$ absorption (Pezhsky, 1993; Kozlowowski, 1997; Larcher, 2004).

In flooded environments, the level of oxygen in the roots decreases drastically due to the displacement of water in the soil, under these conditions fermentation what is a less efficient process than breathing is increased and can lead the plant to the exhaustion of energy, besides intoxicating them with the excessive accumulation of ethanol. These conditions can lead to cell lysis in a few hours or days, depending on the adaptation of each species (Taiz et al., 2017).

For water use efficiency (WUE) there was no significant difference between treatments. This condition can be explained by the fact that the plants have been submitted for a short time to flooding. Bertolde et al. (2012), evaluating the resistance of clones of Theobroma cacao L. under the effect of flooding, noting that the cacao tree presented a reduction in the efficient use of water only after 40 days after flooding, corroborating the results found in this study.

In summary, the liquid assimilation of $\mathrm{CO}_{2}$, stomatal conductance and transpiration rate showed a decrease in the cacao tree grafting of the genotype CCN 51 on the TSH 1188 genotype, and the results were felt in only two days of flooding. On the other hand, the seedlings showed mechanisms of tolerance to stress with a gradual increase the liquid assimilation of $\mathrm{CO}_{2}$ eight days after flooding.

\section{Conclusion}

The gas exchange of cacao plants were influenced in relation to the flooding period in which they were submitted. On the fourth day after flooding, the seedlings underwent stress with a decrease in the values liquid assimilation of $\mathrm{CO}_{2}$, stomatal conductance and transpiration rate. Above this period the seedlings developed morphological modifications that allowed them to adapt to the conditions improving the liquid assimilation of $\mathrm{CO}_{2}$.

\section{References}

Alvares, C. A., Stape, J. L, Sentelhas, P. C., Gonçalves, J. L. M., \& Sparovek, G. (2014). Köppen's climate classification map for Brazil. Meteorologische Zeitschrift, 22(6), 711-728. https://doi.org/10.1127/09412948/2013/0507

Bailey-Serres, J., \& Voesenek L. A. C. J. (2008). Flooding stress: Acclimations and genetic diversity. Annual Review of Plant Biology, 59, 313-339. https://doi.org/10.1146/annurev.arplant.59.032607.092752

Bertolde, F. Z. (2007). Respostas fisiológicas ao alagamento do substrato e diversidade genética molecular de clones de Theobroma cacao L. (107 f., Master Dissertation, Universidade Estadual de Santa Cruz, Ilhéus, Bahia, Brazil).

Bertolde, F. Z., Almeida, A. A. F., Pirovani, C. P., Gomes, F. P., Ahnert, D., Baligar, V. C., \& Valle, R. R. (2012). Physiological and biochemical responses of Theobroma cacao L. genotypes to flooding. Photosynthetica, 50(3), 447-457. https://doi.org/10.1007/s11099-012-0052-4

Dennis, E. S., Dolferus, R., Ellis, M., Rahman, M., Wu, Y., Hoeren, F. U., ... Peacock, W. J. (2000). Molecular 
strategies for improving waterlogging tolerance in plants. Journal Experimental Botany, 51(342), 89-97. https://doi.org/10.1093/jexbot/51.342.89

Kalaji, M. H., Goltsev, V. N., Żuk-Gołaszewska, K., Zivcak, M., \& Brestic, M. (2017). Chlorophyll fluorescence: Understanding crop performance-basics and applications (1st ed.). Boca Raton: CRC Press. https://doi.org/ $10.1201 / 9781315153605$

Kozlowski, T. T. (1997). Responses of woody plants to flooding and salinity. Tree Physiology Monograph, 1, 1-29. https://doi.org/10.1093/treephys/17.7.490

Larcher, W. (2004). Ecofiosiologia vegetal. São Carlos: Rima.

Mielke, M. S., Almeida, A. A. F., Gomes, F. P., Mangabeira, P. A. O., \& Silva, D. C. (2005). Efects of soil flooding on leaf gas exchange and growth of two neotropical pioneer tree species. New For., 29(2), 161-168. https://doi.org/10.1007/s11056-005-0247-7

Oliveira, A. K. M., \& Gualtieri, S. C. J. (2017). Gas exchange and tolerance deegree in young plants of Tabebuia aurea 'paratudo', under flooding. Ciência Florestal, 27(1), 181-191. https://doi.org/10.5902/198050 9826457

Pareek, A., Sopory, S. K., Bohnert, H., \& Govindjee. (2010). Abiotic stress adaptation in plants: Physiological, molecular and genomic foundation. Annals of Botany, 107(4), vii-ix. https://oi.org/10.1093/aob/mcr053

Parolin, P., \& Wittmann, F. (2010). Struggle in the flood: Tree responses to flooding stress in four tropical floodplain systems. AoB Plants, 1-19. https://doi.org/10.1093/aobpla/plq003

Pezeshki, S. R. (1993). Differences in patterns of photosynthetic responses to hypoxia in flood-tolerant and flood-sensitive tree species. Photosynthetica, 28, 423-430.

Pires, J. L. F., Soprano, E., \& Cassol, B. (2002). Morphophysiologic changes of soybean in flooded soils. Pesquisa Agropecuária Brasileira, 37(1), 41-50. https://doi.org/10.1590/S0100-204X2002000100006

R Core Team. (2018). R: A language and environment for statistical computing. Vienna: R Foundation for Statistical Computing, Vienna, Austria.

Taiz, L., Zeiger, E., Moller, I. M., \& Murphy, A. (2017). Fisiologia e desenvolvimento vegetal (6th ed.). Porto Alegre: Artmed.

Vivian, R., Dourado Neto, D., Silva, A. A., Victoria Filho, R., Yeda, M. P., \& Ruiz-Corrêa, S. (2013). Growth analysis of coatbutton in competition with soybean under water deficit. Planta Daninha, 31(3), 599-610. https://doi.org/10.1590/S0100-83582013000300012

\section{Copyrights}

Copyright for this article is retained by the author(s), with first publication rights granted to the journal.

This is an open-access article distributed under the terms and conditions of the Creative Commons Attribution license (http://creativecommons.org/licenses/by/4.0/). 